\title{
p-Pyridinyl oxime carbamates: synthesis, DNA binding, DNA photocleaving activity and theoretical photodegradation studies
}

\author{
Panagiotis S. Gritzapis ${ }^{1}$, Panayiotis C. Varras ${ }^{1}$, Nikolaos-Panagiotis Andreou ${ }^{1}$, \\ Katerina R. Katsani ${ }^{2}$, Konstantinos Dafnopoulos ${ }^{1,3}$, George Psomas ${ }^{3}$, Zisis V. Peitsinis ${ }^{4}$, \\ Alexandros E. Koumbis ${ }^{4}$ and Konstantina C. Fylaktakidou ${ }^{*} 1,4, \S$
}

\section{Full Research Paper}

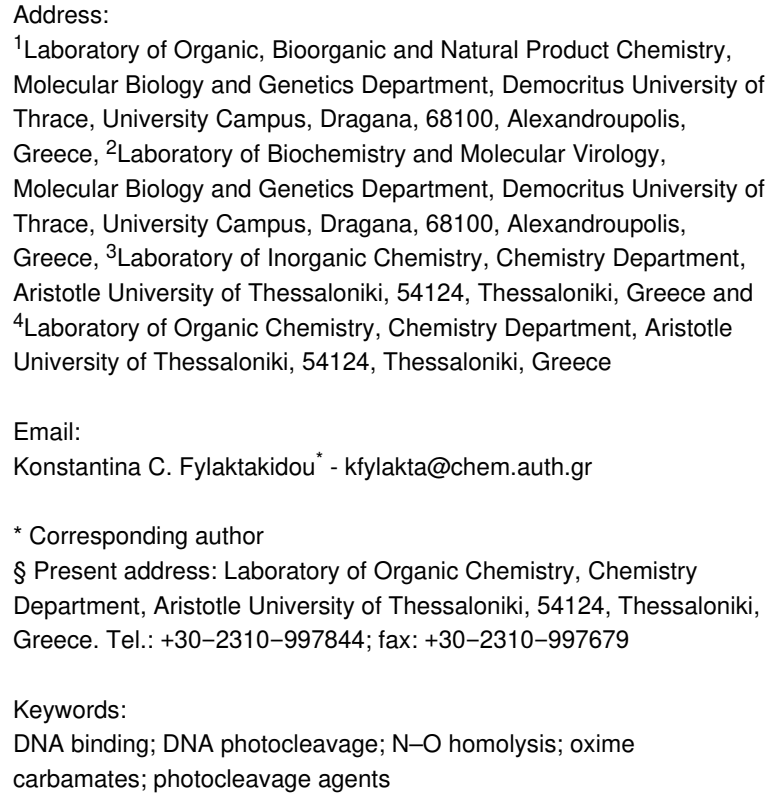

${ }^{1}$ Laboratory of Organic, Bioorganic and Natural Product Chemistry, Molecular Biology and Genetics Department, Democritus University of Thrace, University Campus, Dragana, 68100, Alexandroupolis, Greece, ${ }^{2}$ Laboratory of Biochemistry and Molecular Virology, Molecular Biology and Genetics Department, Democritus University of Thrace, University Campus, Dragana, 68100, Alexandroupolis, Greece, ${ }^{3}$ Laboratory of Inorganic Chemistry, Chemistry Department, Aristotle University of Thessaloniki, 54124, Thessaloniki, Greece and ${ }^{4}$ Laboratory of Organic Chemistry, Chemistry Department, Aristotle University of Thessaloniki, 54124, Thessaloniki, Greece

Email:

Konstantina C. Fylaktakidou* - kfylakta@chem.auth.gr

* Corresponding author

$\S$ Present address: Laboratory of Organic Chemistry, Chemistry

Department, Aristotle University of Thessaloniki, 54124, Thessaloniki,

Greece. Tel.: +30-2310-997844; fax: +30-2310-997679

Keywords:

DNA binding; DNA photocleavage; $\mathrm{N}-\mathrm{O}$ homolysis; oxime

carbamates; photocleavage agents \author{
doi:10.3762/bjoc. 16.33 \\ Received: 03 December 2019 \\ Accepted: 19 February 2020 \\ Published: 09 March 2020 \\ Associate Editor: D. Spring
}

Beilstein J. Org. Chem. 2020, 16, 337-350.

(c) 2020 Gritzapis et al.; licensee Beilstein-Institut. License and terms: see end of document.

\begin{abstract}
A number of $p$-pyridinyl oxime carbamate derivatives were prepared upon the reaction of the corresponding oximes with isocyanates. These novel compounds reacted photochemically in the presence of supercoiled plasmid DNA. Structure-activity relationship (SAR) studies revealed that the substituent on the imine group was not affecting the extend of the DNA damage, whereas the substituent of the carbamate group was critical, with the halogenated derivatives to be able to cause extensive single and double stranded DNA cleavages, acting as "synthetic nucleases", independently of oxygen and pH. Calf thymus-DNA affinity studies showed a good-to-excellent affinity of selected both active and non-active derivatives. Preliminary theoretical studies were performed, in an effort to explain the reasons why some derivatives cause photocleavage and some others not, which were experimentally verified using triplet state activators and quenchers. These theoretical studies seem to allow the prediction of the activity of derivatives able to pass intersystem crossing to their triplet energy state and thus create radicals able to damage DNA. With this study,
\end{abstract}


it is shown that oxime carbamate derivatives have the potential to act as novel effective photobase generating DNA-photocleavers, and are proposed as new leads for "on demand" biotechnological applications in drug discovery and medicine.

\section{Introduction}

Small organic molecules able to bind DNA provide promises for anticancer activity due to alteration of the structure and function of the genetic material. Amongst a plethora of such binders [1-8], various oxime derivatives were found to show affinity towards DNA [9-12], whereas others were found to cleave DNA as metal-free artificial nucleases [13,14].

The interaction of molecules with DNA and their affinity towards this macromolecule also plays a key role in photosensitization techniques. Light activated oxidative DNA cleaving agents are called "DNA photocleavers". These compounds are able to absorb light and to be selectively excited. A variety of reaction mechanisms are initiated, which, aiming to the photocleaver, may lead to DNA damage. A requirement for nucleic acid's and most protein's "transparency" is irradiating at wavelengths longer than $310 \mathrm{~nm}$ [15]. "Transparency" means lack of damage due to irradiation itself and action via its combination with the photosensitizer. It is worth mentioning that, mainly in dermatology, even UVB irradiation is considered of therapeutic use [16-18]. Besides the anticancer activities of photosensitizers [19-21], "post-antibiotic era" is experimenting with photosensitizers as alternative therapeutics for the fight against multiresistant bacteria both for medicinal [22-25] and environmental purposes [26,27].

Several organic compounds were found to be "DNA photocleavers", exhibiting their action at $312 \mathrm{~nm}$, like $[1,2,4]$ triazolo[4,3-a]quinoxaline [28] and quinoxalin-4(5H)one [29] derivatives, various enediyne [30-32], proflavine [33], $\mathrm{N}$-nitroso carboxamide [34], naphazoline [35] and triazole [36] derivatives, azido carbonyl compounds [37] and $N, O$-diacyl-4benzoyl- $N$-phenylhydroxylamines [38].

$O$-Acyl amidoximes, ketoximes and aldoximes (I, II and III, respectively, Figure 1) are also recognized as DNA "photocleavage" agents owing their action to the homolysis of their vulnerable N-O bond, at $312 \mathrm{~nm}$ [9,39-43] or $365 \mathrm{~nm}[44,45]$ yielding photogenerated carbonyloxyl radicals (CRs), which are able to cause oxidative DNA damage. We have recently reported the DNA photocleavage from sulfonylamidoximes and ethanone oximes (IV and V , Figure 1), which were found to attack DNA via sulfonyloxyl radicals (SRs) [10,11]. All the above radical species exhibit photoreactivity towards DNA.

Those oxime derivatives are considered photoacid generators (PAGs) since one of the residual fragments produced by the

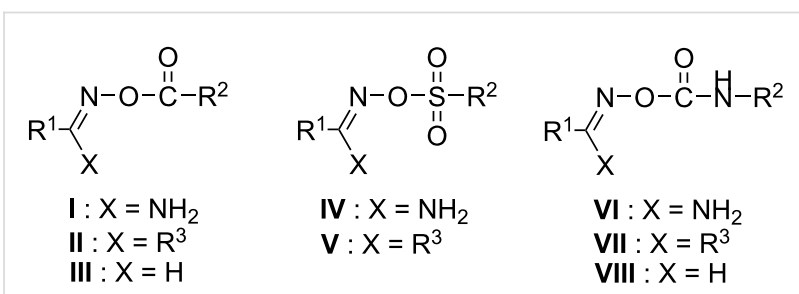

Figure 1: General structures of oxime derivatives with possible DNA photocleavage ability. Left: Oxime carboxylates: $O$-acyl amidoximes (I), $O$-acyl ketoximes (II), $O$-acyl aldoximes (III). Centre: Oxime sulfonates: $O$-sulfonyl amidoximes (IV), O-sulfonyl ketoximes (V). Right: Oxime carbamates: $O$-carbamoyl amidoximes (VI), O-carbamoyl ketoximes (VII) and O-carbamoyl aldoximes (VIII).

$\mathrm{N}-\mathrm{O}$ homolytic cleavage is a carboxylic or a sulfonic acid, generated upon hydrogen abstraction from the corresponding oxygen centred radicals, carbonyloxyl and sulfonyloxyl, respectively. Some are used in the field of photoresists for semiconductor fabrication [46,47]. Oxime carboxylic or sulfonic esters also produce nitrogen-centered iminyl $\left(\mathrm{R}_{2} \mathrm{C}=\mathrm{N}^{\cdot}\right)$ or amidinyl $\left[\mathrm{R}\left(\mathrm{NH}_{2}\right) \mathrm{C}=\mathrm{N}^{\cdot}\right]$ radicals, nevertheless, their damage towards DNA was not well recognized and, thus, DNA photocleavage aimed by nitrogen-centered stable organic radicals has been less investigated. Reports involve arylaminyl radicals ( $\mathrm{ArNH}^{-}$) formed from arylhydrazones through the photoinduced cleavage of $\mathrm{N}-\mathrm{N}$ single bonds (along with an iminyl radical) [48] or from benzotriazole derivatives after also a $\mathrm{N}-\mathrm{N}$ single bond cleavage and nitrogen elimination [36]. It has been reported that aminecentred radicals are also produced from 2-(1-naphthylmethyl)imidazoline [35], whereas acylaminyl radicals $\left[\mathrm{R}(\mathrm{COR}) \mathrm{N}^{\cdot}\right]$ are formed from the photocleavage of the $\mathrm{N}-\mathrm{O}$ bond of $\mathrm{N}, \mathrm{O}$-diacyl- $\mathrm{N}$-phenylhydroxylamines, along with a carbonyloxyl radical [38].

The photochemistry of $O$-carbamoyl oximes (or oxime carbamates) is well studied. These compounds are categorized as highly photoreactive photobase generators (PBGs), providing amines upon rapid decarboxylation of the initially formed carbamoyloxyl radicals $\left(\mathrm{R}_{2} \mathrm{NCOO}\right)$ [49-53]. To the best of our knowledge oxime carbamates have never been photocleaved in the presence of DNA. Based on our interest in the chemistry and biology of the oxime functionality [54-57], as well as in their DNA photolytic interaction upon UV irradiation [9-11,43] we have decided to investigate the behaviour of carefully designed $O$-carbamoyl derivatives of $p$-pyridine amidoxime, ethanone oxime and aldoxime (VI, VII, VIII, $\mathrm{R}_{1}=p$-pyridyl, Figure 1) as DNA photosensitizers. Based on our previous ex- 
perimental results with $o$-, $m$ - and $p$-pyridine oximes as carriers of the carboxylic [9] and sulfonic [11] ester conjugates, we proclaimed $p$-substituted pyridine ring as the most appropriate oxime supporting scaffold for experimenting with our novel carbamate esters, because this ring exhibited a better profile compared to the other pyridine analogues $[9,11]$. In order to provide a structure-activity relationship study, a series of $O$-carbamoyl conjugates consisted of benzyl as well as phenyl groups, bearing electron donating or withdrawing substituents, were synthesized and evaluated.

\section{Results and Discussion Synthesis}

All compounds were synthesized upon the reaction of the appropriate parent $p$-pyridine amidoxime $\mathbf{1}$ [58], ethanone oxime 14 [59] and aldoxime 21 [60] with the corresponding isocyanates 2-7 in good to excellent yields (Scheme 1). When the reactions have been performed at room temperature the yields were poor for most of the products. However, changing the conditions to reflux, the yields were extraordinarily elevated above $90 \%$. The NMR spectra of the products obtained at $\mathrm{rt}$ and under reflux were identical, meaning that no isomerization or decomposition occurred and that the delivered product in both cases is the more thermodynamically stable.

Interestingly, although carbamates are important in both medicinal and polymer chemistry, besides compound 23 [61], all the rest were new. Compounds 8-13 were produced as a sole product, bearing the $Z$-conformation $[9,43,62]$. Their spectroscopic data were in accordance with the proposed structures. In IR spectra all compounds gave 2-3 absorptions above $3200 \mathrm{~cm}^{-1}$ for the $\mathrm{NH}_{2}$ and $\mathrm{NH}$ moieties, and the carbonyl absorption at $1700-1720 \mathrm{~cm}^{-1}$, characteristic of the amide moiety. This low carbonyl absorption probably indicates an intramolecular hydrogen bonding between $\mathrm{NH}_{2}$ and the oxime oxygen, which further verifies the $Z$-conformation of the amidoxime derivatives. The hydroxylimino structure is verified in ${ }^{1} \mathrm{H}$ NMR spectra from the existence of a broad singlet peak, at 6.2-7.1 ppm integrated for two protons $\left(\mathrm{NH}_{2}\right)$, whereas $\mathrm{NH}$ for the aryl derivatives 9-13 appeared in the area 8.9 to $10.2 \mathrm{ppm}$. In a similar way, reactions of compound $\mathbf{1 4}$ with isocyanates delivered a single product with the $E$-configuration [63]. In the IR spectra the NH group appears around $3200-3300 \mathrm{~cm}^{-1}$ and the carbon$\mathrm{yl}$ absorption had the characteristics of an ester, rather than an amide, at 1720 (benzyl derivative, 15) and $1750-1786 \mathrm{~cm}^{-1}$ for compounds with the $\mathrm{NH}$ adjusted on the aromatic ring. In the ${ }^{1} \mathrm{H}$ NMR spectra the $\mathrm{NH}$ of the aryl derivatives 16-20 appeared at 8.1 to $10.7 \mathrm{ppm}$ and for the benzyl derivative $\mathbf{1 5}$ at $6.63 \mathrm{ppm}$.

In the case of aldoxime carbamates three reactions gave mixtures of inseparable $Z$-stereoisomers $\approx 10 \%$ along with the major $E$-stereoisomer (products 25-27). It has been noted in the literature the preferable $E$-conformation for oxime carbamates $[61,64,65]$ where ${ }^{1} \mathrm{H}$ NMR spectroscopy has been used in order to distinguish between the two $[61,65]$. Thus, the imine benzylic proton of the $E$-stereoisomers shows a singlet in the area 8-8.7 ppm, whereas the ones belonging to a $Z$-conformation are upfield and appear between 7.3-7.6 ppm. Indeed, all<smiles>N/C(=N\O)c1ccncc1</smiles><smiles>[R]N=C=O</smiles>
2-7<smiles>C/C(=N\O)c1ccncc1</smiles>

14<smiles>[R]N=C=O</smiles>
2-7<smiles>O/N=C/c1ccncc1</smiles>
21

2, 8, 15, 22: $\mathrm{R}=\mathrm{Ph}-\mathrm{CH}_{2}$ 3, 9, 16, 23: $\mathrm{R}=\mathrm{Ph}$

4, 10, 17, 24: $\mathrm{R}=p-\mathrm{MeO}-\mathrm{Ph}$<smiles>[R]NC(=O)O/N=C(\N)c1ccncc1</smiles>
8-13<smiles>[R]NC(=O)O/N=C(\C)c1ccncc1</smiles><smiles>[R]NC(=O)ON=Cc1ccncc1</smiles>

5, 11, 18, 25: $\mathrm{R}=p-\mathrm{NO}_{2}-\mathrm{Ph}$

6, 12, 19, 26: $\mathrm{R}=p-\mathrm{Cl}-\mathrm{Ph}$

7, 13, 20, 27: $\mathrm{R}=p-\mathrm{F}-\mathrm{Ph}$ 
aldoxime derivatives had the corresponding absorption of the oxime $\mathrm{C}-\mathrm{H}$ in the area $8.3-8.8 \mathrm{ppm}$, and the three products giving the $Z$-stereoisomer showed the same proton upfield at $\approx 8.16 \mathrm{ppm}$.

However, we wanted to further investigate which is the most stable stereoisomer. Thus, ${ }^{1} \mathrm{H}$ chemical shifts of compounds 25-27 were calculated using DFT computational methods with discrete solute-solvent hydrogen bond interactions [66] (see optimized structures in Supporting Information File 1). Geometry optimizations were calculated at the DFT (B3PW91) level, using the $6-31 \mathrm{G}(\mathrm{d})$ basis set. The predicted ${ }^{1} \mathrm{H}$ chemical shifts with GIAO method in PBE0/6-311+G(2d,p) level of theory were in complete agreement with the experimentally found values, allowing us to verify the preferred stereoisomer of compounds 25-27 as $E$. Calculated ${ }^{1} \mathrm{H}$ chemical shifts for $\mathrm{C}(\mathrm{H})=\mathrm{NO}$ proton of the $E$ - and $Z$-stereoisomer compared with the experimental values are shown in Table 1 .

\section{DNA binding studies}

Our previous DNA-binding studies with a series of amidoxime, ethanone oxime and aldoxime carboxylates as well as sulfonates of high, moderate or poor DNA photocleaving ability showed no substantial differences on the DNA affinities among the three kinds of oxime functionalities [9-11]. Thus, in the present study, due to the fact that all three series of oxime derivatives exhibited the same photocleaving activity we have chosen to investigate the DNA affinity of an active and a nonactive DNA photocleaver in order to, hopefully, explain the cause of the activity. Therefore, the interaction of selected compounds, i.e., 11 and 12, with CT DNA was monitored by UV-vis spectroscopy and viscosity measurements. Additionally, the EB-displacing ability of the compounds was evaluated by fluorescence emission spectroscopy. The UV-vis spectra of a CT DNA solution were recorded in the presence of increasing concentrations of the compounds $\left(1.0-1.1 \times 10^{-4} \mathrm{M}\right)$ and are representatively shown for compound $\mathbf{1 1}$ in Figure 2 . The DNA UV-band with $\lambda_{\max }=258 \mathrm{~nm}$ presented upon addition of the compounds a hypochromism which was accompanied by a slight red-shift; such changes may show the binding of the compounds to DNA which may result in the formation of a new conjugate between DNA and the compound under study [67].

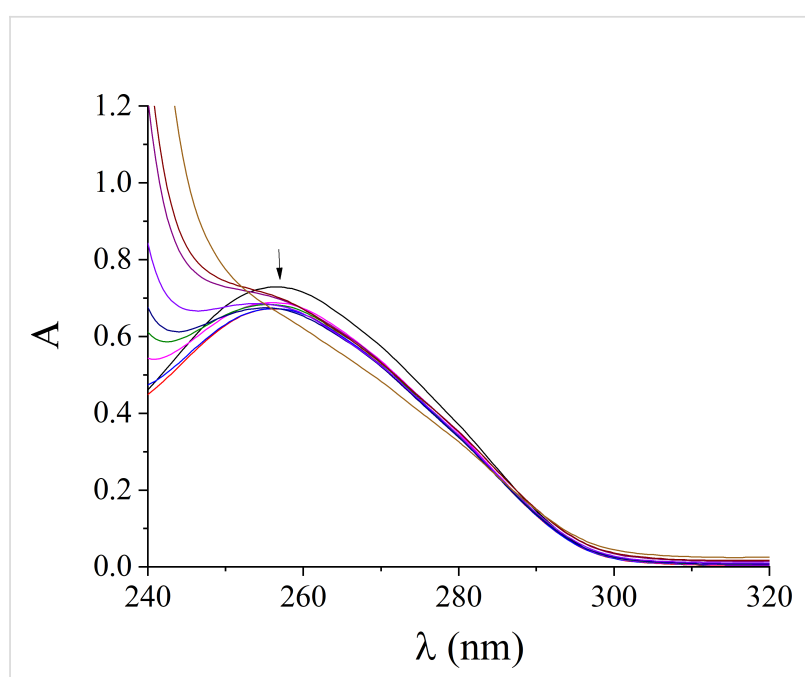

Figure 2: UV-vis spectra of CT DNA ([DNA] $=1.1 \times 10^{-4} \mathrm{M}$ ) in buffer solution in the absence or presence of increasing amounts of compound $11(r=0-0.8)$. The arrow indicates the changes with increasing amounts of the compound.

The UV-vis spectra of the compounds $\left(1 \times 10^{-4} \mathrm{M}\right)$ were recorded in the presence of CT DNA at increasing concentrations (diverse $r$ ' values) (Supporting Information File 1, Figure S-4.1). Both bands of the compound 11 (Supporting Information File 1, Figure S-4.1A) with $\lambda_{\max }$ at $262 \mathrm{~nm}$ and $388 \mathrm{~nm}$ show hypochromism up to $14 \%$ and $2 \%$, respectively, while for the band appearing at $271 \mathrm{~nm}$ a hyperchromism of $12 \%$ is observed. In the UV-vis spectra of compound 12 (Supporting Information File 1, Figure S-4.1B), the bands located at $262 \mathrm{~nm}$ and $297 \mathrm{~nm}$ presented hypochromism of $8 \%$ and $3.5 \%$, respectively, upon addition of CT DNA.

The $\mathrm{K}_{\mathrm{b}}$ constants of the compounds were calculated by the Wolfe-Shimer equation and corresponding plots [DNA] $/\left(\varepsilon_{\mathrm{A}}-\varepsilon_{\mathrm{f}}\right)$ versus [DNA] (Supporting Information File 1, Figure S-4.2) [68]. The $K_{\mathrm{b}}$ constant of $11\left[K_{\mathrm{b}(\mathbf{1 1})}=\right.$ $\left.1.25( \pm 0.20) \times 10^{6} \mathrm{M}^{-1}\right)$ is much notably than that of $\mathbf{1 2}$ $\left(\mathrm{K}_{\mathrm{b}(\mathbf{1 2})}=5.18( \pm 0.10) \times 10^{4} \mathrm{M}^{-1}\right)$, suggesting tighter binding to DNA for compound 11. Especially for compound 11, the $K_{\mathrm{b}}$ constant is higher than the $\mathrm{K}_{\mathrm{b}}$ constant of the classic DNA intercalator $\mathrm{EB}\left(K_{\mathrm{b}}=1.23 \times 10^{5} \mathrm{M}^{-1}\right)$ as previously reported [69].

\begin{tabular}{lllll} 
Table 1: Calculated ${ }^{1} \mathrm{H}$ chemical shifts for $\mathrm{C}(\mathrm{H})=\mathrm{NO}$ proton vs experimental values. & (Exp. = experimental, Calcd = calculated). \\
$\begin{array}{l}\text { Compound } \\
\text { No }\end{array}$ & $\begin{array}{l}\text { Exp. } \mathrm{C}(\mathrm{H})=\mathrm{NO} \text { chemical } \\
\text { shift }(\mathrm{ppm}) \text { E-isomer }\end{array}$ & $\begin{array}{l}\text { Calcd } \mathrm{C}(\mathrm{H})=\mathrm{NO} \text { chemical } \\
\text { shift }(\mathrm{ppm}) \text { E-isomer }\end{array}$ & $\begin{array}{l}\text { Exp. } \mathrm{C}(\mathrm{H})=\mathrm{NO} \text { chemical } \\
\text { shift }(\mathrm{ppm}) \text { Z-isomer }\end{array}$ & $\begin{array}{l}\mathrm{Calcd} \mathrm{C}(\mathrm{H})=\mathrm{NO} \text { chemical } \\
\text { shift }(\mathrm{ppm}) Z \text {-isomer }\end{array}$ \\
\hline 25 & 8.7 & 8.7 & 8.2 & 7.9 \\
26 & 8.7 & 8.6 & 8.2 & 7.8 \\
27 & 8.7 & 8.7 & 8.2 & 7.8
\end{tabular}


The data obtained by the UV-vis spectroscopy studies most probably indicate the interaction of the compounds with CT DNA. However, the exact mode of binding is not safe to be proposed before more experimental data can be collected, i.e., DNA-viscosity measurements [70].

Thus, the monitoring of the DNA viscosity changes when compounds $\mathbf{1 1}$ and $\mathbf{1 2}$ are present, may be elucidating in regard to their binding mode to DNA. As known, the changes of the relative DNA viscosity $\left(\eta / \eta_{0}\right)^{1 / 3}$ are proportionally related to changes of the relative DNA length $\left(L / L_{0}\right)$ [71]. Having this relation in mind, the viscosity of a CT DNA solution $(0.1 \mathrm{mM})$ was determined (Figure 3 ) in the presence of increasing amounts of compounds $\mathbf{1 1}$ and $\mathbf{1 2}$ (up to the value of $r=0.35$ ).

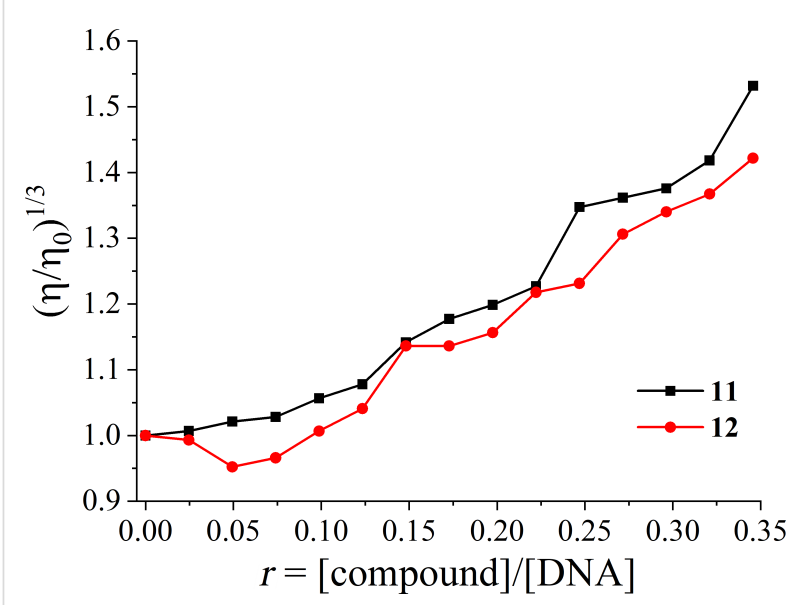

Figure 3: Relative viscosity $\left(\eta / \eta_{0}\right)^{1 / 3}$ of CT DNA $(0.1 \mathrm{mM})$ in buffer solution in the presence of compounds 11 and 12 at increasing amounts.

For compound $\mathbf{1 1}$ the DNA viscosity increases in the presence of the compound. For compound $\mathbf{1 2}$ the DNA viscosity presents a slight decrease up to an $r$ value of 0.07 , and for higher concentrations a noteworthy increase may be observed. Considering the overall changes of the DNA viscosity in the presence of compounds $\mathbf{1 1}$ and 12, we may suggest that compound $\mathbf{1 1}$ shows the behaviour of a typical intercalator while compound 12 may initially interact to CT DNA probably by nonclassical intercalation (i.e., as groove-binder) and as a subsequent step it may probably intercalate within the CT DNA base pairs [11]. Such features may obviously shed light to the findings from the UV-vis spectroscopic studies.

Given the results derived from DNA-viscosity measurements suggesting intercalation as possible interaction mode between compounds 11 and 12 and CT DNA, the determination of the ability of the compounds to displace EB from the EB-DNA conjugate may further clarify and verify their intercalating ability. EB-DNA conjugate exhibits an intense fluorescence emission band at $592 \mathrm{~nm}$, when its solution is excited at $540 \mathrm{~nm}$. Compounds $\mathbf{1 1}$ and $\mathbf{1 2}$ have not presented any appreciable fluorescence emission either alone in solution or in the co-existence of CT DNA or EB under the same experimental conditions ( $\lambda_{\text {excitation }}=540 \mathrm{~nm}$ at room temperature). Thus, the quenching observed in an EB-DNA solution upon addition of the compounds $\mathbf{1 1}$ and $\mathbf{1 2}$ may reveal their competition to EB for the DNA-intercalation sites as monitored by fluorescence emission spectroscopy with $\lambda_{\text {excitation }}=540 \mathrm{~nm}$.

A significant quenching of the EB-DNA fluorescence (up to $68.5 \%$ of the initial fluorescence for compound 12 (Figure 4) was found in the presence of the compounds. The as-observed quenching (which is in good agreement $(R=0.99)$ with the linear Stern-Volmer equation [72]) may be attributed to the competition of compounds $\mathbf{1 1}$ and $\mathbf{1 2}$ with EB for the DNAintercalation sites and may indirectly suggest that the compounds may bind to CT DNA via intercalation $[73,74]$.

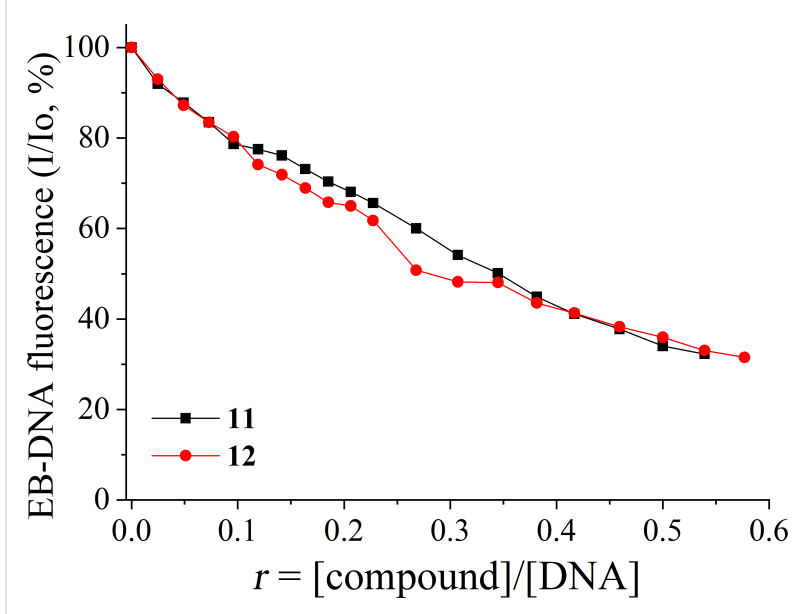

Figure 4: Plot of EB-DNA relative fluorescence emission intensity at $\lambda=592 \mathrm{~nm}\left(I / I_{0}, \%\right)$ vs $r$ (= [compound]/[DNA]) in the presence of compounds 11 and 12 (up to $32.3 \%$ of the initial EB-DNA fluorescence intensity for $\mathbf{1 1}$ and $31.5 \%$ for $\mathbf{1 2}$ ).

The values of the Stern-Volmer constant $\left(K_{\mathrm{SV}}\right)$ were calculated from the corresponding Stern-Volmer plots (Supporting Information File 1, Figure S-4.3). The rather high $K_{\mathrm{SV}}$ values $\left(K_{\mathrm{Sv}(11)}=3.20( \pm 0.08) \times 10^{5} \mathrm{M}^{-1}\right.$ and $K_{\mathrm{Sv}(\mathbf{1 2})}=$ $\left.9.16( \pm 0.16) \times 10^{4} \mathrm{M}^{-1}\right)$ may verify the tight binding of the compounds to CT DNA $[11,73,74]$. More specifically, the $K_{\mathrm{SV}}$ of compound $\mathbf{1 1}$ is higher than that of compound 12, probably suggesting tighter binding to DNA for compound 11 via intercalation, in accordance to the $K_{\mathrm{b}}$ constants and the conclusions from the DNA-viscosity measurements. 


\section{DNA photocleavage studies}

Carbamoyl oxime derivatives 8-13, 15-20 and 22-27 (500 $\mu \mathrm{M})$ were incubated as DMF solutions, with the supercoiled circular pBluescript KS II plasmid DNA (Form I) and this mixture was irradiated with UV light (312 nm) under aerobic conditions at room temperature for $30 \mathrm{~min}$. All experiments were realized at minimum three times, including incubations of all compounds with DNA in dark. All compounds showed at least some UV absorption at the area of irradiation (Figures S-5.1, S-5.2, and S-5.3, Supporting Information File 1). In the presence of the halogenated compounds 12-13, 19-20 and 26-27 the double helix of the supercoiled plasmid DNA (Form I) suffered singlestranded (ss) nicks, generating the relaxed circular DNA (Form II). In several cases, double-stranded (ds) nicks were generated and linear DNA (Form III) appeared as well.

The results regarding the carbamoyl amidoxime 8-13 are depicted in Figure 5A. Ethanone oxime and aldoxime derivatives 15-20 and 22-27 showed quite similar results (for the comparable results see Figure S-6.1, Supporting Information File 1). None of the benzyl (Bn), phenyl (Ph), p-methoxyphenyl (PMP) or $p$-nitrophenyl (PNP) derivatives showed any activity [Figure 5A, wells 3-6, respectively]. On the contrary, both $p$-chlorophenyl (PCP) and $p$-fluorophenyl (PFP) showed the best photocleaving action, exhibiting a percentage of $\mathrm{ds}$ cleavages, as well (Figure 5A, wells 7 and 8, respectively).

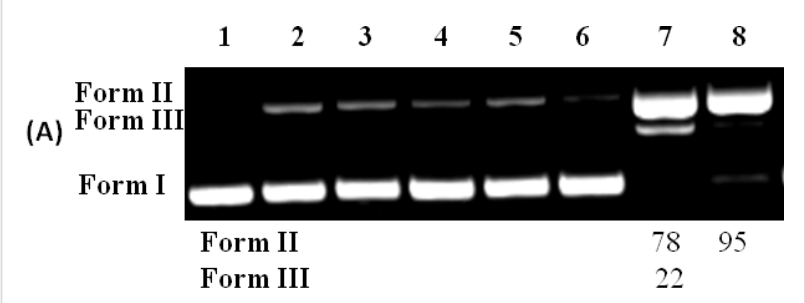

(B)

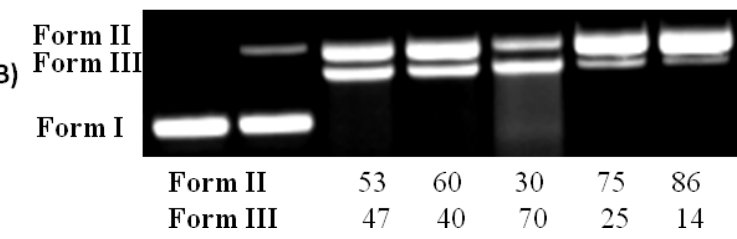

Figure 5: DNA photocleavage of amidoxime carbamates at a concentration of $500 \mu \mathrm{M}$ and mechanistic studies of aldoxime carbamate 26. Gel electrophoreses pictures. For $(A)$ and $(B)$ wells 1 and 2 represent DNA in dark and DNA UV irradiated, respectively. Photo $(A)$ : wells 3-8: DNA + carbamoyl amidoximes (8 or $\mathbf{9}$, or $\mathbf{1 0}$, or $\mathbf{1 1}$, or $\mathbf{1 2}$, or $\mathbf{1 3}$, respectively) + UV irradiation; Photo $(B)$ : Mechanistic studies involved by derivative 26 under UV irradiation: well 3: DNA + 26; well 4: DNA + 26 + argon; well 5: DNA + $\mathbf{2 6}+$ DMSO (20\%); well 6: DNA + 26 + $\mathrm{NaN}_{3}(20 \mathrm{mM})$; well 7: DNA + $26+\mathrm{D}_{2} \mathrm{O}$; Legends: The \% calculated damage of DNA via its conversion to Form II and Form III.

Interestingly, we note that in the series of carbonyl aldoximes, ketoximes and amidoximes $[9,43]$, as well as sulfonyl amidoximes and ethanone oximes [10,11], the PNP derivatives were by far the most active derivatives. Additionally, halogenated sulfonylethanone oxime derivatives were less reactive than the PNP one [10].

Due to the similarity in DNA photocleavage by $p$-pyridine amidoxime, ethanome oxime and aldoxime carbamoyl derivatives, mechanistic studies were performed for two active compounds from the series of amidoximes and aldoximes, 12 and 26, Figure 5B (For the comparable results see Figure S-6.2A and B, Supporting Information File 1).

The mode of action under aerobic conditions does not involve hydroxyl radicals (in fact, DMSO seems to enhance the ds nicks), Figure 5B, well 5. It is possible that excess of this solvent facilitates the radical to escape from the cage. However, performing the same experiment for the rest of the amidoxime derivatives 8-11 (20\% DMSO, data not shown), we did not observe any enhancement of the photocleavage above the statistical error. Counting for the singlet oxygen it is not very clear whether it is implicated or not, since the action is not improved in $\mathrm{D}_{2} \mathrm{O}$, Figure 5B, wells 6 and 7, respectively. Nevertheless, the action under anaerobic conditions is unaffected (Figure 5B, well 4) and the same happens in accordance to the $\mathrm{pH}$ (Supporting Information File 1, Figure S-6.2C). The photocleavage is independent of $\mathrm{pH}$ in the range 5-10. The release of amines from carbamoyl oximes, which may imbalance the $\mathrm{pH}$, and the activity in the absence of oxygen, as well as in various external $\mathrm{pHs}$ may be very fruitful for the treatment of solid tumours, where acidic and hypoxic environments predominate $[75,76]$.

The DNA photocleavage experimental results along with the observations of the DNA affinity experiments, where compound 11 showed tighter binding to DNA than the chloro derivative $\mathbf{1 2}$ and still being inactive towards plasmid DNA upon irradiation, has prompted us to perform photochemical experiments on both latter compounds and check their photoproducts using UV spectrometry. Indeed, when they were irradiated in 1, 2, 5, 10, 15, 20, 25 and 30 min time intervals compound $\mathbf{1 2}$ showed the formation of an intermediate with $\lambda_{\max }$ at $338 \mathrm{~nm}$ which gradually increased, probably indicating a one-way photochemical path during irradiation process. On the other hand, the nitro derivative $\mathbf{1 1}$ showed the formation of an intermediate with $\lambda_{\max }$ at $385 \mathrm{~nm}$ which gradually increased for the first $3 \mathrm{~min}$. This intermediate seems subsequently to act as a light filter absorbing the irradiation energy and to be converted to other products not allowing compound $\mathbf{1 1}$ to act as a DNA photocleaver (Figures S-7.1 and S-7.2, Supporting Information File 1). The study over those two compounds and the explanation of their behaviour has been attempted with more experimentation and is presented below. 


\section{A computational study and photochemical aspects of compounds 11 and 12}

The ground state structures $\left(S_{0}\right)$ for both molecules $\mathbf{1 2}$ and $\mathbf{1 1}$ in their Z-conformations are similar (Figure S-8.1A and B, Supporting Information File 1) with the length of the $\mathrm{N}-\mathrm{O}$ bond varying between $r(\mathrm{~N}-\mathrm{O})=1.423(\mathbf{1 2})$ and $1.425 \AA$ (11). (Table S-8.1, Supporting Information File 1).

The Franck-Condon (FC) vertical excitation energies $\left(\Delta E_{e \mathrm{X}}\right)$ of both molecules in their first triplet $\left(\mathrm{T}_{1}\right)$ and singlet $\left(\mathrm{S}_{1}\right)$ excited states were calculated (Table S-8.2, Supporting Information File 1) using additionally, in order to obtain better excitation energies and wavelengths, the PBE0 functional on the optimized (B3PW91/6-31G(d)) ground state geometries. It is shown, that $\mathbf{1 1}$ has lower excitation energies than $\mathbf{1 2}$ and this must be reflected in the difference between the two substituents $\left(\mathrm{Cl}\right.$ and $\mathrm{NO}_{2}$ ).

Although the two molecules have essentially the same basic chromophore groups when we examine the transitions $\left(\mathrm{S}_{0} \rightarrow \mathrm{T}_{1}\right.$ and $S_{0} \rightarrow S_{1}$ ) we find that there are major differences in the nature of the transitions. In particular, for the transition $\mathrm{S}_{0} \rightarrow \mathrm{T}_{1}$ the excitation is localized on the pyridine moiety for $\mathbf{1 2}$, while for $\mathbf{1 1}$ it is localized on the $p$-nitrophenyl group. As far as the $S_{0} \rightarrow S_{1}$ vertical transition is concerned, for molecule 12 the excitation is localized again on the pyridine ring (involving a $\pi^{*}$ molecular orbital), whereas for $\mathbf{1 1}$ the excitation is of $\pi(\mathrm{O}-\mathrm{N}-\mathrm{O}) \rightarrow \pi^{*}($ nitrophenyl) type.

These observations differentiate the two molecules giving them different photochemical characteristics and properties. We note that the adiabatic excitation energy of $\mathbf{1 2}$ (including the zeropoint energy, ZPE) is $\Delta_{0}\left[\mathrm{~T}_{1}-\mathrm{S}_{0}\right]=53.40 \mathrm{kcal} / \mathrm{mol}$, which corresponds to a wavelength of $535.6 \mathrm{~nm}$ (visible region). The ground state $\left(\mathrm{S}_{0}\right)$ bond dissociation energies (BDE), $D_{0}$, for both molecules under consideration, are shown in Table 2 and were calculated using Gaussian 09 software program package [77].

\begin{tabular}{|c|c|c|}
\hline No & 11 & 12 \\
\hline$D_{0}$ & 51.54 & 41.38 \\
\hline$\Delta_{0}\left[T_{1}-S_{0}\right]$ & 57.29 & 53.40 \\
\hline
\end{tabular}

The BDE difference between the two compounds is about $10 \mathrm{kcal} / \mathrm{mol}$, while that in their adiabatic excitation energies is $3.9 \mathrm{kcal} / \mathrm{mol}$. Since $\Delta_{0}-D_{0}$ is higher for $\mathbf{1 2}$ than $\mathbf{1 1}$ someone would expect $\mathbf{1 2}$ to be more reactive in the $\mathrm{T}_{1}$ state as com- pared to 11, something which is confirmed from our calculations shown below.

It is well known that compounds characterized by triplet energies higher than BDEs should exhibit high reactivity [78,79]. After excitation to the $T_{1}$ FC point, 12 having enough energy reaches $\mathrm{T}_{1} \mathrm{~min}$. From there, dissociation of the $\mathrm{N}-\mathrm{O}$ bond starts to take place and proceeds uphill through a transition state, $\mathrm{T}_{1}$ (TS), the structure of which was optimized fully. Vibrational analysis gives a single imaginary frequency $\left(-550.12 \mathrm{~cm}^{-1}\right)$ which corresponds to the $\mathrm{N}-\mathrm{O}$ bond stretching confirming that the optimized structure is a first order saddle point. Relaxed PES scan was performed until complete dissociation to the respective ground state radicals occurred. In Figure 6 we plot the variation of the energy for $\mathbf{1 2}$ in the $\mathrm{T}_{1}$ state with respect to the reaction coordinate which is the $\mathrm{N}-\mathrm{O}$ bond distance, $r_{\mathrm{N}-\mathrm{O}}$.

For the dissociation reaction of compound $\mathbf{1 2}$ in the triplet state, the molecule passes through a very small energy barrier and dissociates finally into its photoproducts which are the two ground state radicals indicated in Scheme 2.

The almost negligible change in geometry on going from $\mathrm{T}_{1}$ min to $\mathrm{T}_{1}$ (TS) is reflected in the low value of the activation entropy, $\Delta S^{\neq}=0.474 \mathrm{cal} / \mathrm{mol} \cdot \mathrm{K}$, which means that there is a very small disorganization in the transition state as compared to the reactant in the $T_{1}$ minimum state. The length of the bond $\mathrm{N}-\mathrm{O}$ in the transition state is equal to $1.629 \AA$.

The corresponding activation energy (Equation 1) and free activation energy (Equation 2) were calculated for compound 12 and found 3.14 and $2.95 \mathrm{kcal} / \mathrm{mol}$, respectively. These values were used in Equation 3 in order to calculate the rate constant for the $\mathrm{N}-\mathrm{O}$ bond dissociation. Accordingly, $k r$, was found to be $4.27 \cdot 10^{10} \mathrm{~s}^{-1}$, which is a very large value, indicating a fast $\mathrm{N}-\mathrm{O}$ bond dissociation for compound $\mathbf{1 2}$. Equations $1-3$ are described in the theoretical calculations section.

As soon as the two radicals (amidinyl and $p$-chlorocarbamoyloxyl) are formed, the second radical starts to decarboxylate according to the chemical reaction below (Scheme 3 ).

The activation free energy for the decarboxylation reaction is only $1.09 \mathrm{kcal} / \mathrm{mol}$ and by using Equation 4 (see theoretical calculations section) we find a rate constant $k_{\mathrm{r}}=9.87 \cdot 10^{11} \mathrm{~s}^{-1}$, characterizing the reaction as an ultrafast one, with a corresponding life-time of the radical $\tau=1 \mathrm{ps}$. This is in complete agreement with the prediction made by McBurney and Walton [51] for the decarboxylation of $\mathrm{N}$-arylcarbamoyloxyl radicals where they were expected to decarboxylate with great rapidity having almost no finite lives. 


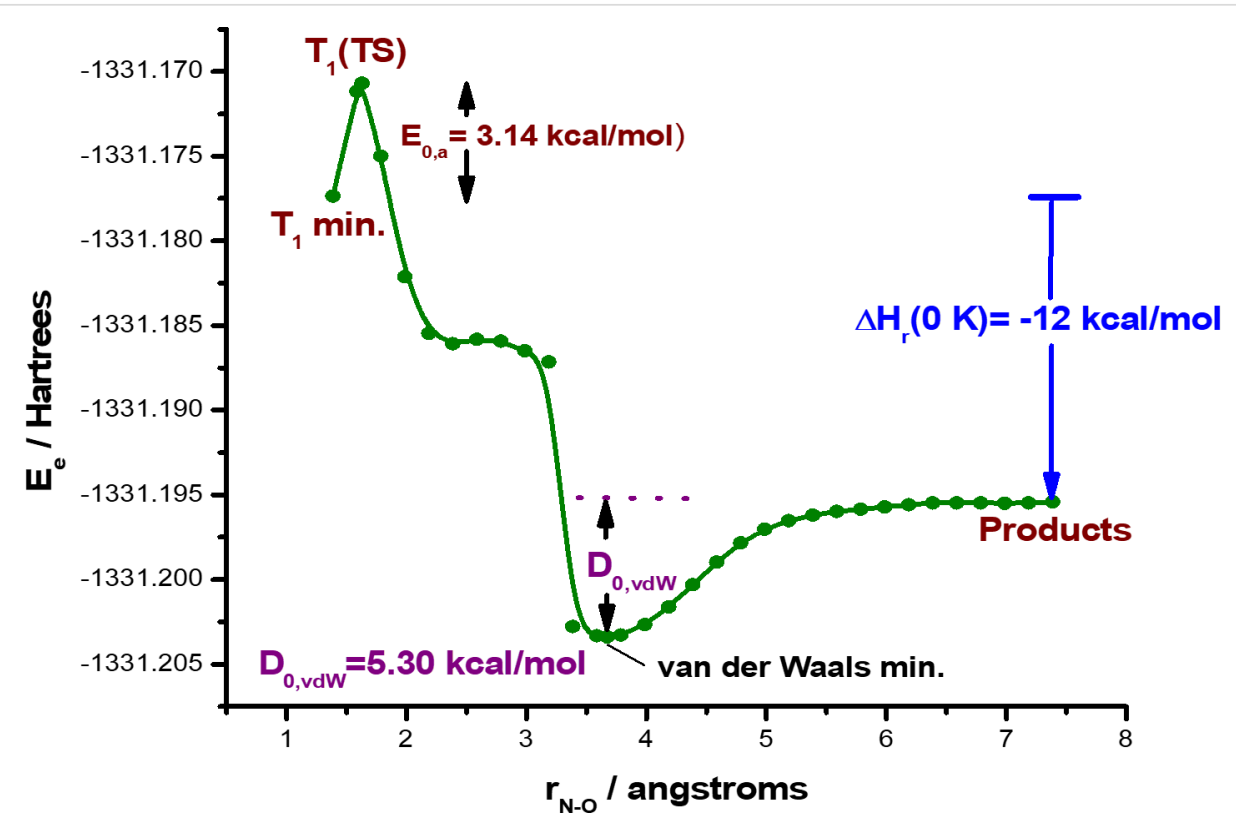

Figure 6: Potential energy curve for the dissociation of 12 in the first excited triplet state, $T_{1}$. For compound 11 see Figure S-8.3, Supporting Information File 1.

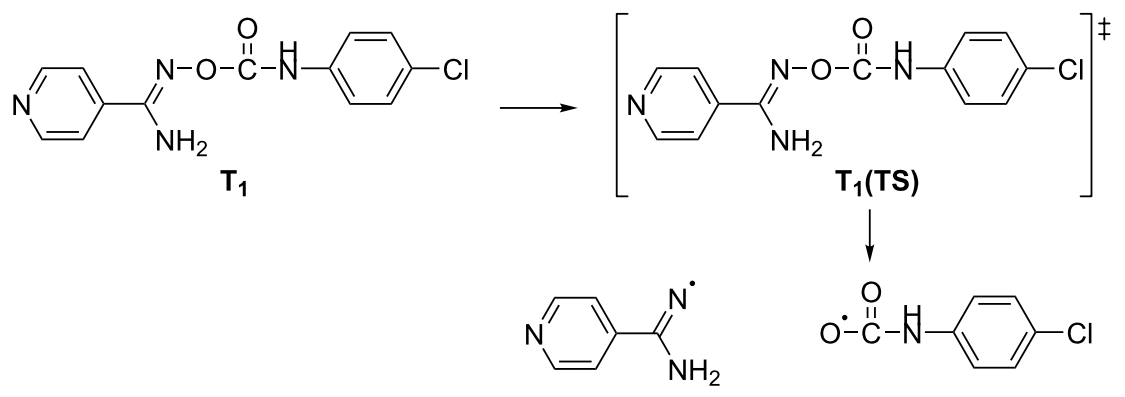

Scheme 2: Photodissociation reaction of the derivative 12 in the $T_{1}$ state and the formation of ground state radicals.

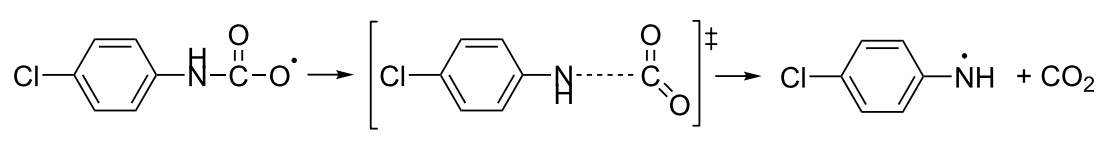

Scheme 3: Decarboxylation reaction of the $p$-chlorophenylcarbamoyloxyl radical.

Excitation of $\mathbf{1 2}$ to the singlet excited state $\left(\mathrm{S}_{1}\right)$ forces the molecule to pass over an energy barrier of approximately $7 \mathrm{kcal} / \mathrm{mol}$ dissociating further and giving ground state radicals again. For the photodissociation of $\mathbf{1 1}$ from either electronic excited state $\left(\mathrm{T}_{1}, \mathrm{~S}_{1}\right)$ calculations show that this is not possible since in this case the intervening energy barriers are very large, $29.37 \mathrm{kcal} / \mathrm{mol}$ for $\mathrm{T}_{1}$ and $31 \mathrm{kcal} / \mathrm{mol}$ for the $\mathrm{S}_{1}$ state. Hence, $\mathbf{1 1}$ does not show any photoreactivity, in accordance with our experimental results.

\section{Photoexcitation in the presence of a triplet state energy activator and a triplet state quencher}

Triplet photosensitizers (TPSs) or triplet state energy activators are compounds that have the ability to be efficiently excited to their triplet excited state. TPSs may be used, among others, to transfer their triplet energy to other molecules that have a low yield of intersystem crossing (ISC) and inefficient production of triplet state $[78,80]$. Acetophenone (AP) is such a compound, 
that when initially excited to its first singlet excited state, exhibits a singlet-to-triplet conversion quantum yield close to $100 \%$ [81] and has been used for its triplet energy transfer [82].

In order to experimentally prove that DNA dissociation occurs from the triplet state of oxime carbamates, when the system has the ability to pass ISC to the triplet energy state, as in the case of compound $\mathbf{1 2}$ (and accordingly all halogenated compounds of the series) we have designed the following experiment: We hypothesized that, upon selective excitation oxime carbamates 8-13 might be excited at their triplet states via triplet state energy transfer from acetophenone as a sensitizer, dissociate to their iminyl/carbamoyloxyl and subsequent anilinyl radicals, attack DNA and cleave it (Figure 7).

As shown in Figure 8 none of the compounds show any cleavage at $365 \mathrm{~nm}$ in the absence of AP (wells 3-7), nevertheless in the presence of the photosensitizer they are able to cause DNA photocleavage around 50\% (wells 9-13). AP itself is inactive towards DNA, under the experimental conditions (well 8).
Finally, we have used triplet energy quenchers such as fluorenone (FL) and carotene (CR), which exhibit low triplet state energy ( $\approx 50$ and $19 \mathrm{kcal} / \mathrm{mol}$, respectively) [83] and may, acting as a triplet quencher, accept energy transfer from oxime carbamate 12, having now the latter compound as the sensitizer. In this case we expect to have decrease or elimination of the activity of compound 12. The results are shown in Figure 9.

It is obvious that in the presence of increasing concentrations of FL the activity of $\mathbf{1 2}$ gradually decreases (wells 4-6) until it is totally eliminated (well 7). Additionally, in the presence of CR as a quencher, the energy of the triplet state of $\mathbf{1 2}$ is transferred to CR and DNA is not damaged (well 10).

\section{Conclusion}

$p$-Pyridyl oxime carbamates bearing electron-donating or electron-withdrawing substituents on the aromatic carbamate group and an amine, a methyl or a hydrogen on the imine moiety, were successfully synthesized in high yields and subjected to UV irradiation in the presence of plasmid DNA. Not all derivatives were active, nevertheless all amidoxime, ethanone oxime and aldoxime derivatives showed similar effects, indicating the

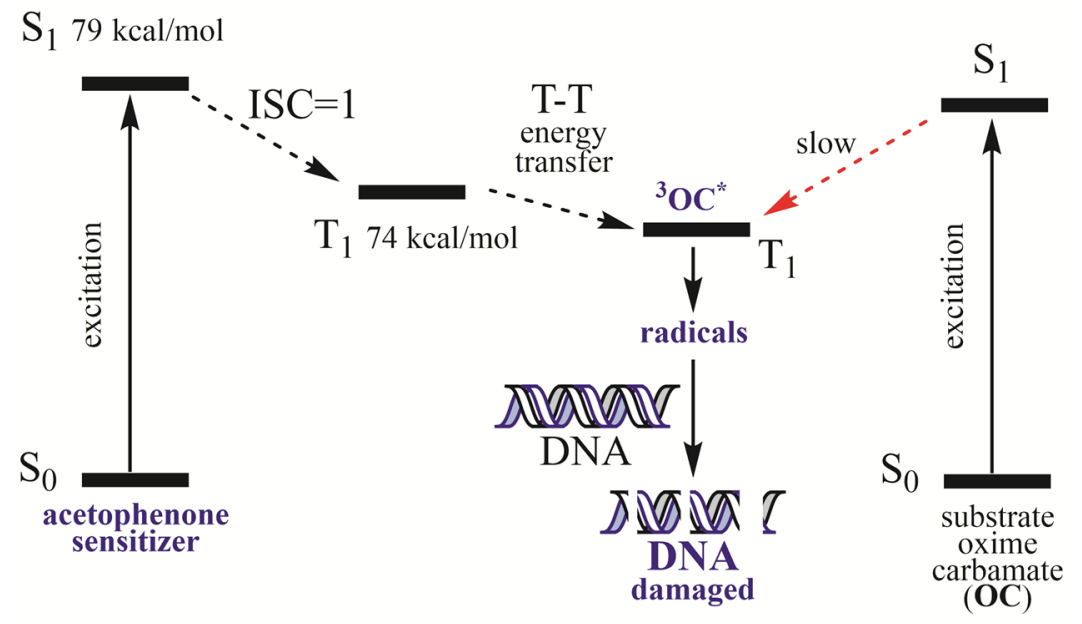

Figure 7: Proposed scheme showing a possible energy transfer from acetophenone sensitizer to oxime carbamate substrate.

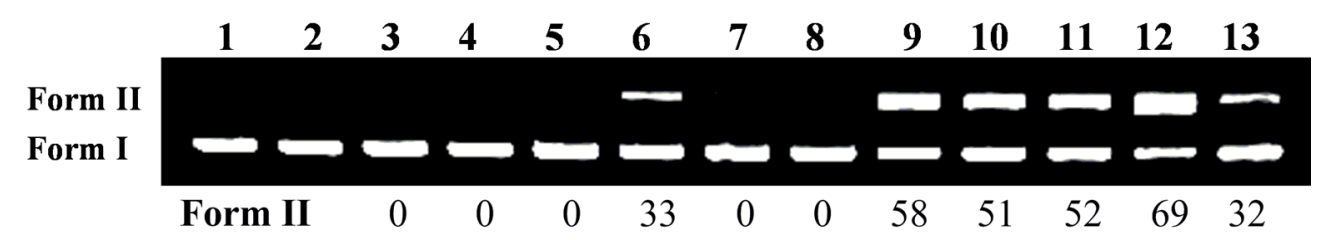

Figure 8: DNA photocleavage of compounds 8-10 and 12-13 at concentration of $500 \mu \mathrm{M}$, at $365 \mathrm{~nm}$, in the absence and presence of acetophenone (AP, $1 \mathrm{mM}$, absorption $\approx 0.1$ at $365 \mathrm{~nm}$ ), $2 \mathrm{~h}, 10 \mathrm{~cm}$ distance, aerobic conditions. wells 1 and 2 represent DNA in dark and DNA UV irradiated, respectively. Photo: wells $3-8$ : DNA $+\mathbf{8}$, or $\mathbf{9}$, or $\mathbf{1 0}$, or $\mathbf{1 2}$, or $\mathbf{1 3}+$ UV, respectively; well 8: DNA + AP + UV; wells 9-13: DNA + 8, or 9, or 10, or $\mathbf{1 2}$, or $\mathbf{1 3}+$ $A P+U V$, respectively. 


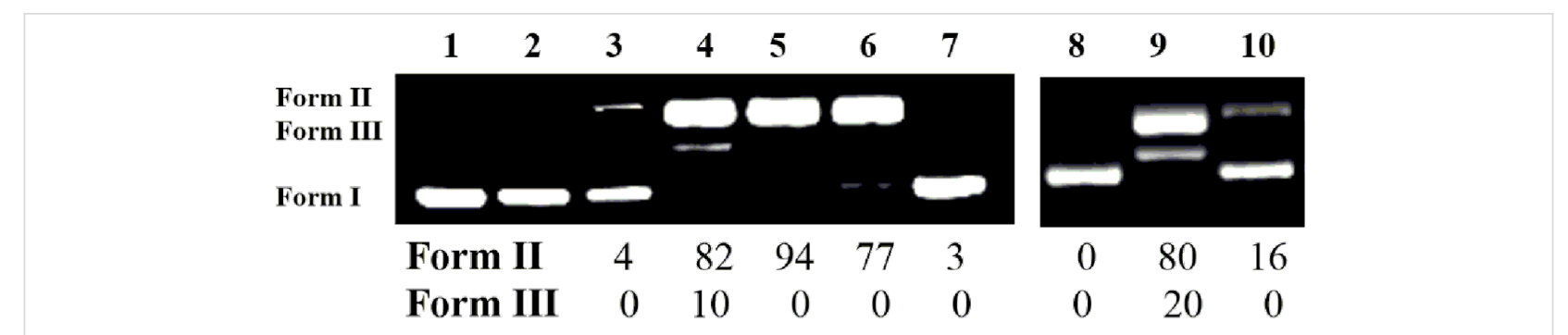

Figure 9: DNA photocleavage of compound 12 at a concentration of $500 \mu \mathrm{M}$, at $312 \mathrm{~nm}$, in the absence and presence of $\mathrm{FL}$ and $\mathrm{CR}$, as quenchers wells 1 and 2 represent DNA in dark and DNA UV irradiated, respectively. Photo: well 3: DNA + FL (100 $\mu M)+U V ;$ wells 4-7: DNA + 12 + UV + FL $(10$, or 25 , or 50 , or $100 \mu \mathrm{M}$, respectively; well 8: DNA + CR $(200 \mu \mathrm{M})+$ UV; lane 9: DNA + 12 + UV; lane 10: DNA + 12 + CR $(200 \mu \mathrm{M})+$ UV.

cause of action to be considered on the carbamate moiety rather than the oxime. The affinity of selective compounds with DNA was good to excellent, as verified with extensive CT DNAaffinity studies.

A deeper insight in the photochemical behaviour of the nitro (11) and the chloro (12) derivatives using UV spectroscopy in the absence of DNA was indicative of the disruption of $\mathbf{1 1}$ whereas 12 showed a gradual formation of one product. A theoretical photochemical dissociation study resulted to the observation that $\mathbf{1 2}$ has the ability to dissociate, as expected, with homolysis of its $\mathrm{N}-\mathrm{O}$ bond overcoming very low energy barriers with high rate constants, on the contrary to $\mathbf{1 1}$, where its photochemical activity seems to be located at the nitro group. The explanation of the activity seems to be the ability of $\mathbf{1 2}$ to obtain its triplet state and create active radicals able to abstract hydrogen atoms from DNA and cause its damage. This was experimentally verified using acetophenone, as a triplet state sensitizer, which transferred its energy to inactive oxime carbamates and enabled them to damage DNA. Additionally, the activity of compound $\mathbf{1 2}$ was diminished when triplet state quenchers as fluorenone and carotene were introduced into the irradiated DNA mixture.

Accordingly, halogenated carbamate derivatives, of both amidoxime, ethanone oxime and aldoxime derivatives showed, similarly, significant DNA photocleavage. Mechanistic studies on DNA photocleavage showed that these "synthetic nucleases" act independently of oxygen and $\mathrm{pH}$. As photobase generators, upon the homolysis of their $\mathrm{N}-\mathrm{O}$ bond, oxime carbamates are able to release amines which in in vivo action may imbalance the $\mathrm{pH}$ of the tissues, and still retain the ability to create radicals. The same applies to hypoxic environments and anaerobic conditions.

Finally, with this study, we have shown that oxime carbamate derivatives have the potential to act as novel effective photobase generating DNA-photocleavers with predicted DNA photocleaving, able, as well, to be subjected to photoinduced sensitizing. Thus as a novel class of photocleavers, oxime carbamates may serve in the discovery of new leads for "on demand" biotechnological, technological and medical applications.

\section{Experimental \\ Materials and methods}

All commercially available reagent grade chemicals and solvents were used without further purification. Dry solvents were purchased from Sigma-Aldrich Co. Calf-thymus (CT) DNA, ethidium bromide (EB), $\mathrm{NaCl}$ and trisodium citrate were purchased from Sigma-Aldrich Co. CT DNA stock solution was prepared according to standard procedures [84]. The CT DNA concentration was determined by the UV absorbance at $260 \mathrm{~nm}$ after 1:20 dilution using $\varepsilon=6600 \mathrm{M}^{-1} \mathrm{~cm}^{-1}$ [85].

High-resolution mass spectra (HRMS) were recorded on micrOTOF GC-MS QP 5050 Shimadzu single-quadrupole mass spectrometer. UV-visible (UV-vis) spectra were recorded on a Hitachi U-2001 dual beam spectrophotometer. Fluorescence emission spectra were recorded in solution on a Hitachi F-7000 fluorescence spectrophotometer. Viscosity experiments were carried out using an ALPHA L Fungilab rotational viscometer equipped with an $18 \mathrm{~mL}$ LCP spindle and the measurements were performed at $100 \mathrm{rpm}$. All samples were irradiated with Philips $2 \times 9 \mathrm{~W} / 01 / 2 \mathrm{P}$ UV-B narrowband lamps at $312 \mathrm{~nm}$.

Melting points were measured on a Kofler hot-stage apparatus or a melting point meter M5000 KRÜSS, and are uncorrected. FTIR spectra were obtained in a Perkin-Elmer 1310 spectrometer using potassium bromide pellets. NMR spectra were recorded on an Agilent 500/54 (500 MHz and $125 \mathrm{MHz}$ for ${ }^{1} \mathrm{H}$ and ${ }^{13} \mathrm{C}$, respectively) spectrometer using $\mathrm{CDCl}_{3}$, and/or DMSO- $d_{6}$ as solvent. Chemical shifts are given in ppm and $J$ values in $\mathrm{Hz}$ using solvent as an internal reference. All reactions were monitored on commercial available pre-coated TLC plates (layer thickness $0.25 \mathrm{~mm}$ ) of Kieselgel 60 F254. Yields were calculated after recrystallization. 


\section{Synthesis of carbamates}

All compounds were synthesized upon the reaction of the appropriate parent $p$-pyridine amidoxime $\mathbf{1}$ [58], ethanone oxime 14 [59] and aldoxime 21 [60] with the corresponding isocyanates 2-7 in good to excellent yields (Scheme 1). All carbamates are new, besides compound 23 [61]. For each compound, all spectroscopic and other data were collected in order to establish identity. General procedures for the syntheses, as well as data and pictures of all spectra are provided in Supporting Information File 1.

\section{Interaction with CT DNA DNA-binding studies with UV-vis spectroscopy}

The binding constants of compounds $\mathbf{1 1}$ and $\mathbf{1 2}$ to CT DNA $\left(K_{\mathrm{b}}\right)$ were calculated by the Wolfe-Shimer equation $[11,68]$ using UV-vis spectroscopy, in order to estimate their interaction of with CT DNA.

\section{DNA-viscosity studies}

The viscosity of CT DNA ([DNA] $=0.1 \mathrm{mM})$ in buffer solution $(150 \mathrm{mM} \mathrm{NaCl}$ and $15 \mathrm{mM}$ trisodium citrate at $\mathrm{pH}$ 7.0) was measured in the presence of increasing amounts of compounds $\mathbf{1 1}$ and $\mathbf{1 2}$ (up to the value of $r=0.35$ ) [11].

\section{EB-displacement studies}

The ability of compounds $\mathbf{1 1}$ and $\mathbf{1 2}$ to displace EB from its DNA-EB conjugate was investigated by fluorescence emission spectroscopy. The Stern-Volmer constant $\left(K_{\mathrm{SV}}\right.$, in $\left.\mathrm{M}^{-1}\right)$ was used to evaluate the quenching efficiency for each compound according to the Stern-Volmer equation $[11,72]$.

\section{DNA cleavage experiments}

All synthesized $O$-carbamoyl oximes were incubated with supercoiled circular Bluescript KS II DNA and irradiated at 312 or $365 \mathrm{~nm}$ for $30 \mathrm{~min}$ and $2 \mathrm{~h}$, respectively. The mixture was subjected to electrophoresis, the gel was visualized by $312 \mathrm{~nm}$ UV transilluminator and photographed. Finally, quantitation of DNA-cleaving activities was performed using the program "Image J" available at the site http://rsb.info.nih.gov/ij/download.html and the single-strand ( $\mathrm{ss} \%)$ as well as double-strand $(\mathrm{ds} \%)$ damage was calculated, using a correction factor of 1.43 [11].

\section{Theoretical calculations \\ Calculations for the photodegradation of carbamates}

The structures, properties and the basic photochemistry of compounds 11 and 12 was studied using the density functional theory (DFT) method [86-89] and the functional B3PW91 along with the $6-31 \mathrm{G}(\mathrm{d})$ basis set. This functional has been found to describe accurately the bond dissociation process [90]. Further- more, all calculations were carried out in aqueous solution using the polarizable continuum model with the integral equation formalism (IEFPCM). All relevant structures were optimized fully and characterized accordingly as stationary points (minima or maxima) on the corresponding potential energy surfaces (PESs).

Equations 1-5 were used for the calculations of the rates and the physicochemical data of the $\mathrm{N}-\mathrm{O}$ bond dissociation of the most active compound $\mathbf{1 2}$ in radicals. The corresponding activation energy and free energy of activation are given in Equation 1 and Equation 2, respectively:

$$
\begin{gathered}
\Delta E_{0} \ddagger=E_{0}\left(\mathrm{~T}_{1} / T S\right)-E_{0}\left(\mathrm{~T}_{1 \text { min }}\right) \\
\Delta G \ddagger=G\left(\mathrm{~T}_{1} / T S\right)-G\left(\mathrm{~T}_{1 \text { min }}\right)
\end{gathered}
$$

For the calculation of the rate constant, $k_{r}$, the Eyring's classical Equation 3 was used, where in the above equation $k_{B}$ is the Boltzmann's constant $\left(1.380662 \cdot 10^{-23} \mathrm{~J} / \mathrm{K}\right), h$ is the Planck's constant $\left(6.626176 \cdot 10^{-34} \mathrm{~J} \cdot \mathrm{s}\right), R$ is the universal gas constant $(1.987 \mathrm{kcal} / \mathrm{mol} \cdot \mathrm{K})$ and $T$ is the absolute temperature in $\mathrm{K}$.

$$
k_{\mathrm{r}}=\kappa \frac{k_{\mathrm{B}} \cdot T}{h} \cdot e^{-\Delta G^{\neq} / R T}
$$

Improvement of the Eyring's equation, incorporating the quantum mechanical tunnelling coefficient, $\kappa$, was also used, Equation 4 . The quantum phenomenon in this case is the tunnelling of the electrons of the bond under dissociation, that is, the $\mathrm{N}-\mathrm{O}$ bond which constitutes the potential well.

$$
k_{\mathrm{r}}=\kappa \frac{k_{\mathrm{B}} \cdot T}{h} \cdot \frac{Q^{\neq}}{Q_{\mathrm{R}}} e^{-\Delta E_{0}^{\neq} / R T}
$$

In Equation $4 Q^{\neq}$and $Q_{\mathrm{R}}$ represent the molecular partition functions in the transition state and in $\mathrm{T}_{1}$ min with their values being $0.241907 \cdot 10^{24}$ and $0.184606 \cdot 10^{24}$, respectively. Additionally, Equation 5 was used to calculate the quantum mechanical tunneling coefficient by employing the Skodje-Truhlar potential for parabolic potential barriers [91].

$$
\kappa(T)=\sum_{n=0}^{\infty}(-1)^{n} \beta \cdot\left[\frac{1-e^{\left\{[\beta-(n+1) \alpha] \cdot \Delta E_{0}^{\neq}\right\}}}{(n+1) \alpha-\beta}+\frac{1}{n \alpha+\beta}\right]
$$


In Equation 5 the parameters $\alpha=2 \pi / \mathrm{h} \cdot \operatorname{Im}\left(v^{\neq}\right)=$ $5.74672 \cdot 10^{20} \mathrm{~J}^{-1}$ and $\beta=1 / k_{\mathrm{B}} \cdot T=2.42928 \cdot 10^{20} \mathrm{~J}^{-1}$ are defined through the fundamental constants, $v^{\neq}$is the imaginary frequency of the transition state corresponding to that normal mode of vibration which takes the transition state towards the product without a restoring force. In our case, $v^{\neq}=550.12 i \mathrm{~cm}^{-1}$ and $\operatorname{Im}\left(v^{\neq}\right)=550.12 \mathrm{~cm}^{-1}=1.64921 \cdot 10^{13} \mathrm{~s}^{-1}$, which is a real number.

Finally, the $\mathrm{N}-\mathrm{O}$ bond energies were calculated according to previously reported methods [9].

\section{Supporting Information}

The Supporting Information features 1) general procedures for the synthesis of all compounds and data analysis; 2) ${ }^{1} \mathrm{H}$ NMR and ${ }^{13} \mathrm{C}$ NMR of amidoxime, ethanone oxime and aldoxime carbamates; 3 ) Optimized structures of compounds 25-27 with the ab initio DFT computational methods, 4) DNA binding studies; 5) UV absorption spectra of all amidoxime, ethanone oxime and aldoxime carbamates; 6) Gel electrophoresis pictures of all amidoxime, ethanone oxime and aldoxime carbamate; 7) UV absorption spectra of amidoxime carbamates $\mathbf{1 1}$ and 12 under irradiation; 8) A computational study and photochemical aspects of compounds $\mathbf{1 1}$ and $\mathbf{1 2}$.

\section{Supporting Information File 1}

Experimental part.

[https://www.beilstein-journals.org/bjoc/content/ supplementary/1860-5397-16-33-S1.pdf]

\section{Acknowledgements}

We thank the ProFI (Proteomics Facility at IMBB-FORTH) for performing all the HRMS analyses and Assoc. Prof. A. K. Zarkadis (Univ. of Ioannina, Chemistry Department) for helpful discussions and for access to the Gaussian 09, Revision B.01 program. The authors declare no competing financial interest.

\section{ORCID ${ }^{\circledR}$ iDs}

Panayiotis C. Varras - https://orcid.org/0000-0003-4280-5475 George Psomas - https://orcid.org/0000-0002-5879-7265 Konstantina C. Fylaktakidou - https://orcid.org/0000-0002-2186-2617

\section{References}

1. Paul, A.; Bhattacharya, S. Curr. Sci. 2012, 102, 212-231.

2. Ali, A.; Bhattacharya, S. Bioorg. Med. Chem. 2014, 22, 4506-4521. doi:10.1016/j.bmc.2014.05.030

3. Sirajuddin, M.; Ali, S.; Badshah, A. J. Photochem. Photobiol., B 2013, 124, 1-19. doi:10.1016/j.jphotobiol.2013.03.013
4. Portugal, J. Biochem. Pharmacol. 2018, 155, 336-345. doi:10.1016/j.bcp.2018.07.030

5. Salem, O. M.; Vilková, M.; Janočková, J.; Jendželovský, R.; Fedoročko, P.; Imrich, J.; Kožurková, M. Med. Chem. Res. 2017, 26, 2309-2321. doi:10.1007/s00044-017-1931-9

6. Salem, O.; Vilkova, M.; Plsikova, J.; Grolmusova, A.; Burikova, M.; Prokaiova, M.; Paulikova, H.; Imrich, J.; Kozurkova, M. J. Chem. Sci. 2015, 127, 931-940. doi:10.1007/s12039-015-0851-9

7. Salem, O. M.; Vilková, M.; Janočková, J.; Jendželovský, R.; Fedoročko, P.; Žilecká, E.; Kašpárková, J.; Brabec, V.; Imrich, J.; Kožurková, M. Int. J. Biol. Macromol. 2016, 86, 690-700. doi:10.1016/j.ijbiomac.2016.02.018

8. Dileep, K. V.; Vijeesh, V.; Remya, C. Mol. BioSyst. 2016, 12, 860-867. doi:10.1039/c5mb00808e

9. Pasolli, M.; Dafnopoulos, K.; Andreou, N.-P.; Gritzapis, P. S.; Koffa, M.; Koumbis, A. E.; Psomas, G.; Fylaktakidou, K. C. Molecules 2016, 21 , 864. doi:10.3390/molecules21070864

10. Andreou, N.-P.; Dafnopoulos, K.; Tortopidis, C.; Koumbis, A. E.; Koffa, M.; Psomas, G.; Fylaktakidou, K. C. J. Photochem. Photobiol., B 2016, 158, 30-38. doi:10.1016/j.jphotobiol.2016.02.017

11. Papastergiou, A.; Perontsis, S.; Gritzapis, P.; Koumbis, A. E.; Koffa, M.; Psomas, G.; Fylaktakidou, K. C. Photochem. Photobiol. Sci. 2016, 15, 351-360. doi:10.1039/c5pp00439j

12. Janockova, J.; Zilecka, E.; Kasparkova, J.; Brabec, V.; Soukup, O.; Kuca, K.; Kozurkova, M. Mol. BioSyst. 2016, 12, 2910-2920. doi:10.1039/c6mb00332j

13. Reddy, D. S.; Kongot, M.; Netalkar, S. P.; Kurjogi, M. M.; Kumar, R.; Avecilla, F.; Kumar, A. Eur. J. Med. Chem. 2018, 150, 864-875. doi:10.1016/j.ejmech.2018.03.042

14. Fernandes, L.; Fischer, F. L.; Ribeiro, C. W.; Silveira, G. P.; Sá, M. M.; Nome, F.; Terenzi, H. Bioorg. Med. Chem. Lett. 2008, 18, 4499-4502. doi:10.1016/j.bmcl.2008.07.052

15. Armitage, B. Chem. Rev. 1998, 98, 1171-1200. doi:10.1021/cr960428+ 16. Ibbotson, S. H. Front. Med. 2018, 5, No. 184. doi:10.3389/fmed.2018.00184

17. Motschenbacher, S.; Buder, K.; Goebeler, M.; Kerstan, A. Eur. J. Dermatol. 2012, 22, 803-804. doi:10.1684/ejd.2012.1857

18. Coricovac, D.; Farcas, C.; Nica, C.; Pinzaru, I.; Simu, S.; Stoian, D.; Soica, C.; Proks, M.; Avram, S.; Navolan, D.; Dumitru, C.; Popovici, R. A.; Dehelean, C. A. Int. J. Mol. Sci. 2018, 19, 3600. doi:10.3390/ijms 19113600

19. Yu, G.; Zhu, B.; Shao, L.; Zhou, J.; Saha, M. L.; Shi, B.; Zhang, Z.; Hong, T.; Li, S.; Chen, X.; Stang, P. J. Proc. Natl. Acad. Sci. U. S. A. 2019, 116, 6618-6623. doi:10.1073/pnas.1902029116

20. Zhang, J.; Tavares de Sousa Júnior, W.; Mello da Silva, V. C.; Rodrigues, M. C.; Vasconcelos Morais, J. A.; Song, J.-L.; Cheng, Z.-Q.; Longo, J. P. F.; Bentes Azevedo, R.; Jiang, C.-S.; Muehlmann, L. A.; Zhang, H. Molecules 2018, 23, 1436. doi:10.3390/molecules23061436

21. Zhao, X.; Huang, Y.; Yuan, G.; Zuo, K.; Huang, Y.; Chen, J.; Li, J.; Xue, J. Chem. Commun. 2019, 55, 866-869. doi:10.1039/c8cc09456j

22. Hamblin, M. R. Curr. Opin. Microbiol. 2016, 33, 67-73. doi:10.1016/j.mib.2016.06.008

23. Nakonieczna, J.; Wozniak, A.; Pieranski, M.; Rapacka-Zdonczyk, A.; Ogonowska, P.; Grinholc, M. Future Med. Chem. 2019, 11, 443-461. doi:10.4155/fmc-2018-0329

24. Tomb, R. M.; White, T. A.; Coia, J. E.; Anderson, J. G.; MacGregor, S. J.; Maclean, M. Photochem. Photobiol. 2018, 94 , 445-458. doi:10.1111/php.12883

25. Sobotta, L.; Skupin-Mrugalska, P.; Piskorz, J.; Mielcarek, J. Dyes Pigm. 2019, 163, 337-355. doi:10.1016/j.dyepig.2018.12.014 
26. Maraccini, P. A.; Wenk, J.; Boehm, A. B. J. Appl. Microbiol. 2016, 121, 587-597. doi:10.1111/jam.13183

27. Maraccini, P. A.; Wenk, J.; Boehm, A. B. Environ. Sci. Technol. 2016, 50, 5050-5059. doi:10.1021/acs.est.6b00074

28. Aggarwal, R.; Sumran, G.; Kumar, V.; Mittal, A. Eur. J. Med. Chem. 2011, 46, 6083-6088. doi:10.1016/j.ejmech.2011.10.032

29. Sumran, G.; Aggarwal, R.; Mittal, A.; Aggarwal, A.; Gupta, A. Bioorg. Chem. 2019, 88, 102932. doi:10.1016/j.bioorg.2019.102932

30. Kar, M.; Basak, A. Chem. Rev. 2007, 107, 2861-2890. doi:10.1021/cr068399i

31. Yang, W.-Y.; Roy, S.; Phrathep, B.; Rengert, Z.; Kenworthy, R.; Zorio, D. A. R.; Alabugin, I. V. J. Med. Chem. 2011, 54, 8501-8516. doi:10.1021/jm2010282

32. Breiner, B.; Kaya, K.; Roy, S.; Yang, W.-Y.; Alabugin, I. V. Org. Biomol. Chem. 2012, 10, 3974-3987. doi:10.1039/c2ob00052k

33. Kuroda, R.; Shinomiya, M. Biochem. Biophys. Res. Commun. 1991, 181, 1266-1272. doi:10.1016/0006-291x(91)92075-u

34. Hwu, J. R.; Huang, J. J.-T.; Tsai, F.-Y.; Tsay, S.-C.; Hsu, M.-H.; Hwang, K. C.; Horng, J.-C.; Ho, J.-a. A.; Lin, C.-C. Chem. - Eur. J. 2009, 15, 8742-8750. doi:10.1002/chem.200802571

35. Sortino, S.; Giuffrida, S.; Scaiano, J. C. Chem. Res. Toxicol. 1999, 12, 971-978. doi:10.1021/tx9900526

36. Wender, P. A.; Touami, S. M.; Alayrac, C.; Philipp, U. C. J. Am. Chem. Soc. 1996, 118, 6522-6523. doi:10.1021/ja960647c

37. Chowdhury, N.; Dutta, S.; Karthick, S.; Anoop, A.; Dasgupta, S.; Pradeep Singh, N. D. J. Photochem. Photobiol., B 2012, 115, 25-34. doi:10.1016/j.jphotobiol.2012.06.006

38. Chowdhury, N.; Dutta, S.; Nishitha, B.; Dasgupta, S.; Singh, N. D. P. Bioorg. Med. Chem. Lett. 2010, 20, 5414-5417. doi:10.1016/j.bmcl.2010.07.116

39. Hwu, J. R.; Tsay, S.-C.; Hong, S. C.; Leu, Y.-J.; Liu, C.-F.; Chou, S.-S. P. Tetrahedron Lett. 2003, 44, 2957-2960. doi:10.1016/s0040-4039(03)00375-7

40. Hwu, J. R.; Tsay, S.-C.; Hong, S. C.; Hsu, M.-H.; Liu, C.-F.; Chou, S.-S. P. Bioconjugate Chem. 2013, 24, 1778-1783. doi:10.1021/bc400060h

41. Hwu, J. R.; Yang, J.-R.; Tsay, S.-C.; Hsu, M.-H.; Chen, Y.-C.; Chou, S.-S. P. Tetrahedron Lett. 2008, 49, 3312-3315. doi:10.1016/j.tetlet.2008.03.056

42. Chou, S.-S. P.; Juan, J.-C.; Tsay, S.-C.; Huang, K. P.; Hwu, J. R. Molecules 2012, 17, 3370-3382. doi:10.3390/molecules 17033370

43. Karamtzioti, P.; Papastergiou, A.; Stefanakis, J. G.; Koumbis, A. E.; Anastasiou, I.; Koffa, M.; Fylaktakidou, K. C. Med. Chem. Commun. 2015, 6, 719-726. doi:10.1039/c4md00548a

44. Chowdhury, N.; Dutta, S.; Dasgupta, S.; Singh, N. D. P.; Baidya, M.; Ghosh, S. K. Photochem. Photobiol. Sci. 2012, 11, 1239-1250. doi:10.1039/c2pp25033k

45. Bindu, P. J.; Mahadevan, K. M.; Satyanarayan, N. D.; Ravikumar Naik, T. R. Bioorg. Med. Chem. Lett. 2012, 22, 898-900. doi:10.1016/j.bmcl.2011.12.037

46. Ikbal, M.; Banerjee, R.; Atta, S.; Jana, A.; Dhara, D.; Anoop, A.; Singh, N. D. P. Chem. - Eur. J. 2012, 18, 11968-11975. doi:10.1002/chem.201104065

47. Ikbal, M.; Jana, A.; Singh, N. D. P.; Banerjee, R.; Dhara, D. Tetrahedron 2011, 67, 3733-3742. doi:10.1016/j.tet.2011.03.049

48. Ru Hwu, J.; Chieh Lin, C.; Hsien Chuang, S.; Yung King, K.; Su, T.-R.; Tsay, S.-C. Bioorg. Med. Chem. 2004, 12, 2509-2515. doi:10.1016/j.bmc.2004.03.037

49. Shirai, M.; Tsunooka, M. Bull. Chem. Soc. Jpn. 1998, 71, 2483-2507. doi:10.1246/bcsj.71.2483
50. Tsunooka, M.; Suyama, K.; Okamura, H.; Shirai, M. J. Photopolym. Sci. Technol. 2006, 19, 65-71. doi:10.2494/photopolymer.19.65

51. McBurney, R. T.; Walton, J. C. J. Am. Chem. Soc. 2013, 135, 7349-7354. doi:10.1021/ja402833w

52. Hwang, H.; Jang, D.-J.; Chae, K. H. J. Photochem. Photobiol., A 1999, 126, 37-42. doi:10.1016/s1010-6030(99)00129-x

53. Bucher, G.; Scaiano, J. C.; Sinta, R.; Barclay, G.; Cameron, J. J. Am. Chem. Soc. 1995, 117, 3848-3855. doi:10.1021/ja00118a021

54. Fylaktakidou, K. C.; Hadjipavlou-Litina, D. J.; Litinas, K. E.; Varella, E. A.; Nicolaides, D. N. Curr. Pharm. Des. 2008, 14, 1001-1047. doi:10.2174/138161208784139675

55. Nicolaides, D. N.; Fylaktakidou, K. C.; Litinas, K. E.; Hadjipavlou-Litina, D. Eur. J. Med. Chem. 1998, 33, 715-724. doi:10.1016/s0223-5234(98)80030-5

56. Ispikoudi, M.; Amvrazis, M.; Kontogiorgis, C.; Koumbis, A. E.; Litinas, K. E.; Hadjipavlou-Litina, D.; Fylaktakidou, K. C. Eur. J. Med. Chem. 2010, 45, 5635-5645. doi:10.1016/j.ejmech.2010.09.016

57. Doulou, I.; Kontogiorgis, C.; Koumbis, A. E.; Evgenidou, E.; Hadjipavlou-Litina, D.; Fylaktakidou, K. C. Eur. J. Med. Chem. 2014, 80, 145-153. doi:10.1016/j.ejmech.2014.04.040

58. Borg, S.; Luthman, K.; Nyberg, F.; Terenius, L.; Hacksell, U. Eur. J. Med. Chem. 1993, 28, 801-810. doi:10.1016/0223-5234(93)90115-u

59. Huang, K.; Merced, F. G.; Ortiz-Marciales, M.; Meléndez, H. J.; Correa, W.; De Jesús, M. J. Org. Chem. 2008, 73, 4017-4026. doi:10.1021/j0800204n

60. Zhu, J.; Ye, Y.; Ning, M.; Mándi, A.; Feng, Y.; Zou, Q.; Kurtán, T.; Leng, Y.; Shen, J. ChemMedChem 2013, 8, 1210-1223. doi:10.1002/cmdc.201300144

61. Kocak, A.; Ahmetli, G.; Kocak, N.; Malkondu, S.; Yaylaci, A.; Kurbanli, S. Synth. Commun. 2011, 41, 1629-1637. doi:10.1080/00397911.2010.490627

62. Nicolaides, D. N.; Varella, E. A. The Chemistry of Amidoximes. In The Chemistry of Acid Derivatives; Patai, S., Ed.; John Wiley \& Sons Ltd.: Chichester, UK, 1992; pp 875-966. doi:10.1002/9780470772508.ch16

63. Gattinoni, S.; Simone, C. D.; Dallavalle, S.; Fezza, F.; Nannei, R.; Battista, N.; Minetti, P.; Quattrociocchi, G.; Caprioli, A.; Borsini, F.; Cabri, W.; Penco, S.; Merlini, L.; Maccarrone, M. Bioorg. Med. Chem. Lett. 2010, 20, 4406-4411. doi:10.1016/j.bmcl.2010.06.050

64. Sit, S. Y.; Conway, C. M.; Xie, K.; Bertekap, R.; Bourin, C.; Burris, K. D. Bioorg. Med. Chem. Lett. 2010, 20, 1272-1277. doi:10.1016/j.bmcl.2009.11.080

65. Dalton, D. R.; Foley, H. G. J. Org. Chem. 1973, 38, 4200-4203. doi:10.1021/jo00963a022

66. Siskos, M. G.; Kontogianni, V. G.; Tsiafoulis, C. G.; Tzakos, A. G.; Gerothanassis, I. P. Org. Biomol. Chem. 2013, 11, 7400-7411. doi:10.1039/c3ob41556b

67. Long, E. C.; Barton, J. K. Acc. Chem. Res. 1990, 23, 271-273. doi:10.1021/ar00177a001

68. Wolfe, A.; Shimer, G. H., Jr.; Meehan, T. Biochemistry 1987, 26 , 6392-6396. doi:10.1021/bi00394a013

69. Dimitrakopoulou, A.; Dendrinou-Samara, C.; Pantazaki, A. A.; Alexiou, M.; Nordlander, E.; Kessissoglou, D. P. J. Inorg. Biochem. 2008, 102, 618-628. doi:10.1016/j.jinorgbio.2007.10.005 
70. Pratviel, G.; Bernadou, J.; Meunier, B. DNA and RNA Cleavage by Metal Complexes. Advances in Inorganic Chemistry; Academic Press: San Diego, CA, 1998; Vol. 45, pp 251-312. doi:10.1016/s0898-8838(08)60027-6

71. García-Giménez, J. L.; González-Álvarez, M.; Liu-González, M.; Macías, B.; Borrás, J.; Alzuet, G. J. Inorg. Biochem. 2009, 103, 923-934. doi:10.1016/j.jinorgbio.2009.04.003

72. Lakowicz, J. R. Principles of fluorescence spectroscopy, 3rd ed.; Springer Science+Business Media: New York, NY, USA, 2006.

73. Tarushi, A.; Perontsis, S.; Hatzidimitriou, A. G.; Papadopoulos, A. N.; Kessissoglou, D. P.; Psomas, G. J. Inorg. Biochem. 2015, 149, 68-79. doi:10.1016/j.jinorgbio.2015.02.019

74. Dimiza, F.; Perdih, F.; Tangoulis, V.; Turel, I.; Kessissoglou, D. P.; Psomas, G. J. Inorg. Biochem. 2011, 105, 476-489. doi:10.1016/j.jinorgbio.2010.08.013

75. Trédan, O.; Galmarini, C. M.; Patel, K.; Tannock, I. F. J. Natl. Cancer Inst. 2007, 99, 1441-1454. doi:10.1093/jnci/djm135

76. Song, C. W.; Griffin, R.; Park, H. J. Influence of Tumor pH on Therapeutic Response. In Cancer Drug Resistance. Cancer Drug Discovery and Development; Teicher, B. A., Ed.; Humana Press: Totowa, NJ, 2006; pp 21-42. doi:10.1007/978-1-59745-035-5_2

77. Gaussian 09, Revision B.01; Gaussian, Inc.: Wallingford, CT, 2009.

78. Allonas, X.; Lalevée, J.; Fouassier, J.-P.; Tachi, H.; Shirai, M.; Tsunooka, M. Chem. Lett. 2000, 29, 1090-1091. doi:10.1246/cl.2000.1090

79. Lalevée, J.; Allonas, X.; Fouassier, J. P.; Tachi, H.; Izumitani, A.; Shirai, M.; Tsunooka, M. J. Photochem. Photobiol., A 2002, 151, 27-37. doi:10.1016/s1010-6030(02)00174-0

80. Zhao, J.; Wu, W.; Sun, J.; Guo, S. Chem. Soc. Rev. 2013, 42 , 5323-5351. doi:10.1039/c3cs35531d

81. Huix-Rotllant, M.; Burghardt, I.; Ferré, N. C. R. Chim. 2016, 19, 50-56. doi:10.1016/j.crci.2015.10.002

82. Catalani, L. H.; Wilson, T. J. Am. Chem. Soc. 1987, 109, 7458-7462. doi:10.1021/ja00258a033

83. Montalti, M.; Credi, A.; Prodi, L.; Gandolfi, M. T. Handbook of Photochemistry, 3rd ed.; CRC Press: Boca Raton, FL, U.S.A., 2006. doi:10.1201/9781420015195

84. Marmur, J. J. Mol. Biol. 1961, 3, 208-218. doi:10.1016/s0022-2836(61)80047-8

85. Reichmann, M. E.; Rice, S. A.; Thomas, C. A.; Doty, P. J. Am. Chem. Soc. 1954, 76, 3047-3053. doi:10.1021/ja01640a067

86. Koch, W.; Holthausen, M. C. A Chemist's Guide to Density Functional Theory, 2nd ed.; Wiley-VCH: Weinheim, Germany, 2001. doi:10.1002/3527600043

87. Parr, R. G.; Weitao, Y. Density-functional theory of atoms and molecules; Oxford University Press: New York, NY, USA, 1989.

88. Jensen, F. Introduction to Computational Chemistry; John Wiley \& Sons Ltd.: Chichester, UK, 2007.

89. Cramer, C. J. Essentials of Computational Chemistry, Theories and Models, 2nd ed.; John Wiley \& Sons Ltd.: Chichester, UK, 2008.

90. Alonso, R.; Campos, P. J.; Rodríguez, M. A.; Sampedro, D. J. Org. Chem. 2008, 73, 2234-2239. doi:10.1021/jo7025542

91. Skodje, R. T.; Truhlar, D. G. J. Phys. Chem. 1981, 85, 624-628. doi:10.1021/j150606a003

\section{License and Terms}

This is an Open Access article under the terms of the Creative Commons Attribution License (https://creativecommons.org/licenses/by/4.0). Please note that the reuse, redistribution and reproduction in particular requires that the authors and source are credited.

The license is subject to the Beilstein Journal of Organic Chemistry terms and conditions:

(https://www.beilstein-journals.org/bjoc)

The definitive version of this article is the electronic one which can be found at:

doi:10.3762/bjoc. 16.33 